\title{
Pengembangan Modul IPA Terpadu Berbasis Discovery Learning Untuk Meningkatkan Motivasi Dan Hasil Belajar Peserta Didik Pada Materi Sistem Pernapasan Manusia
}

\author{
Endah Dwicahyani $^{1)}$; Johnson Siallagan ${ }^{2)}$; dan Virman ${ }^{3)}$ \\ ${ }^{1}$ SMP YPK 2 Manokwari; endwichania@gmail.com \\ ${ }^{2}$ Program Studi Magister Pendidikan IPA UNCEN; siallagan68@yahoo.com \\ ${ }^{3}$ Program Studi Magister Pendidikan IPA UNCEN; virman_uncen@yahoo.com
}

\begin{abstract}
Research and development $(R \& D)$ aims to find out how to make integrated science modules based on discovery learning,feasibility of integrated science modules,increase motivation and learning outcomes of students using integrated sciencemodules,advantages and disadvantages of integrated science modules based on discovery learning in human respiratory system material Research results : 1) Development of integrated science modules based on discovery learning in human respiratory system material.2)Feasibility of integrated science learning based on discovery learning from the material validator the results of $91.30 \%$ categories are very feasible, the results of the science teacher $93 \%$ respone categories are very good, the response of limited-scale student is $88.78 \%$ in very good categories.3) increased learning motivation of students by using integrated science modules based on discovery learning in human respiratory system material $81.83 \%$ very high categories,4)Improving student learning outcomes with an average the average pre test value of 39.06 was 70 in the post test and the $n$-Gain 0,51 moderate categories
\end{abstract}

Key words : Respiratory System; Discovery Learning; Motivation

\begin{abstract}
ABSTRAK
Penelitian dan Pengembangan (R \& D) bertujuan untuk mengetahui cara membuat modul IPA terpadu berbasis discovery learning, kelayakan modul IPA terpadu, peningkatan motivasi dan hasil belajar peserta didik dengan menggunakan modul IPA terpadu, kelebihan dan kekurangan modul IPA terpadu berbasis discovery learning pada materi sistem pernapasan manusia.Hasil penelitian : 1) Pengembangan modul IPA terpadu berbasis discovery learning pada materi sistem pernapasan manusia 2) Kelayakan Modul IPA terpadu berbasis discovery learning dari validator materi hasil rerata sebesar 91,30 \% kategori sangat layak, hasil respon guru IPA $93 \%$ kategori sangat baik, respon peserta didik skala terbatas sebesar 88,78 \% kategori sangat baik. 3) Peningkatan motivasi belajar peserta didik dengan menggunakan modul IPA terpadu berbasis discovery learning pada materi sistem pernapasan manusia sebesar $81,83 \%$ kategori sangat tinggi 4) Peningkatan hasil belajar peserta didik dengan rata-rata nilai pretest 39,06 menjadi 70 pada posttest dan uji n-Gain rata-rata 0,51 kategori sedang.
\end{abstract}

Kata Kunci : Sistem Pernapasan; Discovery Learning; Motivasi

\section{PENDAHULUN}

Pendidikan IPA dapat menjadi wahana bagi peserta didik untuk mempelajari diri sendiri dan alam sekitar, serta prospek pengembangan lebih lanjut dan menerapkannya di dalam kehidupan seharihari, untuk memenuhi kebutuhan manusia 
melalui pemecahan masalah yang dapat diindentifikasi Penerapan pembelajaran IPA di Indonesia selama ini, masih berorientasi pada pencapaian nilai tes/ujian sehingga dalam pembelajaran IPA cenderung pada hafalan dan teori sehingga hasil belajar peserta didik rendah, karena tidak dibiasakan untuk belajar berpikir secara mandiri didalam memecahkan suatu masalah, hal ini disebabkan karena rendahnya kemampuan berpikir kritis peserta didik di Indonesia. Pada hasil survei Programme for Internasional Students Assesment PISA 2015, peringkat dan capaian negara Indonesia untuk tahun 2015 meningkat enam peringkat dari peringkat 71 pada 2012 menjadi 64 dari 72 negara. Meskipun peringkatnya meningkat untuk kategori sains, Indonesia masih masuk dalam jajaran negara dengan kualitas sains terendah, dimana Indonesia termasuk kedalam 10 negara dengan rata-rata skor PISA kategori sains terendah.

Peningkatan capaian yang terjadi harus terus ditingkatkan dengan meningkatkan mutu pendidikan di Indonesia.

Pencapaian hasil Ujian (UN) IPA pada tingkat SMP/MTS tahun ajaran 2017/2018 Kementerian Pendidikan dan Kebudayaaan (Kemendikbud) merilis hasil Ujian Nasional Berbasis Komputer (UNBK) sekolah menengah pertama (SMP). Hasilnya, nilai rata-rata UN mengalami penurunan dalam 3 tahun terakhir untuk nilai IPA, pada tahun 2016 berada di angka 61,33, pada tahun 2017 diangka 52,69, dan pada tahun 2018 berada diangka 49,18. sebagaimana di dalam Tabel 1 di bawah ini :

Tabel 1.Nilai rata-rata UNBK 2016-2018.

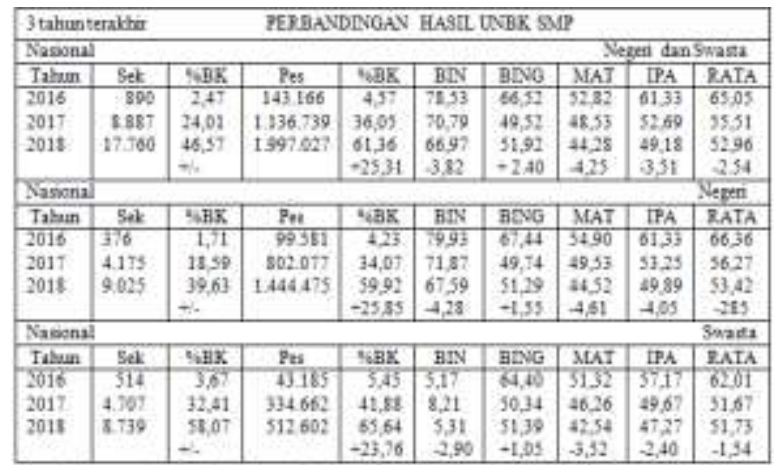

Sumber:https://news.detik.com/berita/4042222/ kemendikbud

Sedangkan Provinsi Papua Barat,

Kabupaten Manokwari nilai UN tahun pelajaran 2017/2018 pada keempat mata pelajaran yang diuji mencapai rerata nilai 59,31 bahasa Indonesia,nilai 48,99 bahasa Inggris,nilai 42,60 matematika dan 46,10 IPA dengan pencapaian nilai rerata total 49,10 tersebut, maka Kabupaten Manokwari berada pada peringkat 11 dari 13 kabupaten yang ada di Provinsi Papua Barat yang ditampilkan pada Tabel 2 sebagai berikut:

Tabel 2: Hasil UN Tingkat SMP/MTS Kabupaten Manokwari Papua Barat.

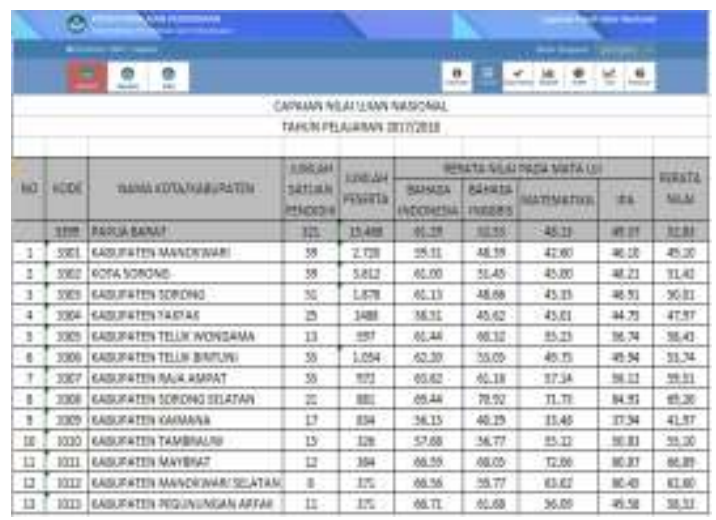

Sumber:https://puspendik.kemdikbud.go.id/hasil-un 
Nilai UN pada mata pelajaran IPA harus mendapatkan perhatian dari semua pihak dalam meningkatkan mutu pendidikan di Kabupaten Manokwari, sehingga dapat mencapai target sesuai dengan harapan pemerintah. IPA terpadu merupakan pembelajaran terpadu pada mata pelajaran Ilmu Pengetahuan Alam (IPA). Model pembelajaran terpadu pada hakikatnya merupakan suatu model pembelajaran yang memungkinkan peserta didik baik secara individual maupun kelompok aktif mencari, menggali, menemukan konsep serta prinsip-prinsip secara holistik dan otentik (Ananda, Rusydi dan Abdillah, 2018 : 28).

Berdasarkan pengalaman peneliti dalam mengajar, metode pembelajaran yang dalam proses kegiatan belajar IPA berlangsung berpusat pada guru sehingga kurang memberikan kesempatan kepada peserta didik untuk mengali kemampuan diri didalam memecahkan suatu masalah yang dihadapi dalam proses pembelajaran. Berdasarkan pada pengalaman tersebut banyak peserta didik yang kurang termotivasi dan berminat untuk belajar IPA, sehingga peserta didik menganggap bahwa pelajaran IPA itu sulit dan membosankan.Hal ini akan menyebabkan peserta didik kurang memperhatikan penjelasan guru pada saat proses pembelajaran berlangsung dan hasil belajar IPA peserta didik menjadi rendah, Permasalahan tersebut perlu mendapatkan pemecahan permasalahan yang tepat, agar proses pembelajaran yang berlangsung di SMP YPK 2 Manokwari dapat terlaksana dengan baik, tepat, serta meningkatkan motivasi dan kemandirian peserta didik dalam belajar. Model pembelajaran discovery learningdipilih untuk memperbaiki proses pembelajaran IPA di SMP YPK 2 Manokwari. Menurut Rosalina Esti Lestari dan Virman (2018), discovery learning adalah suatu model untuk mengembangkan cara belajar aktif dengan menemukan sendiri, menyelidiki sendiri, maka hasil yang diperoleh akan setia dan tahan lama dalam ingatan.

Berdasarkan hasil penelitian yang dilakukan oleh Delisma Wisnu Adi (2016) menyimpulkan bahwa pembelajaran yang menggunakan modul berbasis discovery learning dapat meningkatkan kemampuan berpikir kritis dan kreatif siswa kelas XI SMA/MA di Surakarta.

Penelitian ini bertujuan untuk mengembangkan modul pembelajaran IPA secara terpadu pada materi sistem pernapasan manusia berbasis discovery learning untuk meningkatkan motivasi dan hasil belajar peserta didik di kelas VIII SMP YPK 2 Manokwari.

\section{METODOLOGI PENELITIAN}

Metode penelitian yang digunakan adalah metode penelitian dan pengembangan (Research and Development). Penelitian ini bertujuan untuk menghasilkan suatu produk berupa 
modul pembelajaran IPA berbasis discovery learning pada materi sistem pernapasan manusia dengan harapan dapat dijadikan sebagai penunjang dalam proses pembelajaran serta dapat meningkatkan kualitas mutu pendidikan.

Populasi dalam penelitian ini adalah seluruh peserta didik kelas VIII SMP YPK 2 Manokwari dan sampel penelitian ini pada kelas VIII A dengan jumlah siswa sebanyak 33 orang sebagai kelas penelitian. Dalam pengambilan sampel pada penelitian ini menggunakan teknik purposive sampling. Prosedur penelitian metode Research and Development dapat dilihat pada skema gambar 1 berikut ini :

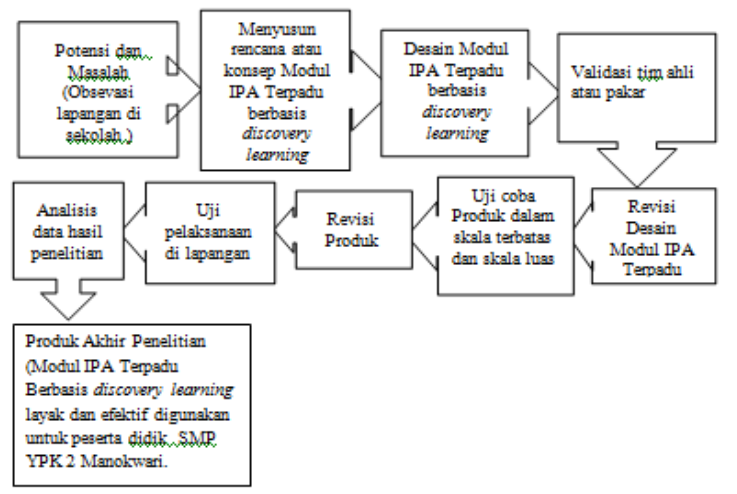

Gambar 1. Skema Prosedur Pengembangan Modul IPA Terpadu Berbasis Discovery Learning dengan Metode Research and Development (dimodifikasi dari Sugiyono, 2016).

Pengumpulan data dalam uji coba menggunakan instrumen penelitian sebagai berikut:

\section{Angket/Kuisoner}

Angket atau kuisioner yang digunakan sebagai penilaian produk untuk mendapatkan data tentang kelayakanmodul hasil pengembangan ditinjau dari aspek kelayakan isi, aspek kebahasaan, dan aspek
penyajian.Kuisioner tersebut diperuntukkan bagi para ahli materi yang memvalidasi modul dilakukan oleh tiga validator.

2. Angket respon peserta didik

Angket diberikan kepada 6 orang peserta didik yang terdiri dari 3 kategori prestasi belajar peserta didik untuk uji terbatas dan untuk uji skala luas angket diberikan kepada peserta didik dikelas penelitian.

3. Angket respon guru

Angket diberikan kepada 3 orang guru IPA sebagai penilaian terhadap produk modul yang dikembangkan.

4. Tes hasil belajar

Instrumen tes hasil belajar untuk mengetahui hasil belajar peserta didik sebelum dan setelah diberikan tindakan berupa pretest dan posttest.

5. Observasi

Observasi dilakukan dengan mengumpulkan data melalui pengamatan langsung terhadap suatu objek dan mencatat secara sistematis tentang hal-hal tertentu yang diamati.

\section{HASIL DAN PEMBAHASAN}

\section{Pembuatan Modul IPA Terpadu} Berbasis Discovery learning Pada Materi Sistem Pernapasan Manusia Kelas VIII SMP YPK 2 Manokwari

Pembuatan modul IPA terpadu berbasis discovery learning pada materi sistem pernapasan manusia peserta didik kelas VIII, diperlukan prosedur tertentu 
sesuai dengan sasaran yang ingin dicapai bagi pengembangan modul pembelajaran yang terdiri dari beberapa cara yaitu : 1) Mengidentifikasi potensi dan masalah dengan cara mengumpulkan informasi melalui analisis peserta didik,analisis konsep dan analisis tujuan pembelajaran.2) Pembuatan Instrumen kuesioner untuk mendapatkan data dan informasi untuk mengetahui kelayakan modul sebelum digunakan. 3) Pembuatan desain modul IPA terpadu berbasis discovery learning pada materi sistem pernapasan manusia yang dilakukan dalam penelitian ini, yaitu: a) menetapkan bidang kajian IPA terpadu antara lain fisika, biologi dan kimia. b) Analisis kompetensi dasar. c) Menentukam tema atau topik berdasarkan kompetensi dasar. d) Merumuskan indikator. e) Menentukan tujuan pembelajaran yang dicapai peserta didik. f) Menentukan metode dalam kegiatan pembelajaran. g) Pembuatan desain modul meliputi halaman muka (cover), halaman kata pengantar dan daftar isi. h) Pembuatan petunjuk penggunaan modul. i) Penulisan bagian pendahuluan, bagian isi, bagian evaluasi, bagian penutup. j) Penulisan glosarium dan daftar pustaka. 4) Validasi modul. 5) Merevisi Desain Modul IPA. 6) Uji Coba Produk dilakukan pada peserta didik kelas VIII dalam kelompok skala terbatas yang dilakukan terhadap 6 orang peserta didik dikelas VIII B,VIII C,VIII D dan masingmasing kelas diambil 2 orang peserta didik secara acak dengan pembelajaran menggunakan modul. Hasil tanggapan peserta didik skala terbatas terhadap modul IPA terpadu yang dikembangkan mendapat skor sebesar $88,78 \%$ dengan kriteria sangat baik dan uji coba dalam skala luas dilaksanakan di kelas VIII A. Pada kelas skala luas data yang diperoleh adalah data motivasi peserta didik dalam bentuk angket yang diberikan pada peserta didik serta observasi yang dilakukan dalam setiap kegiatan pembelajaran, hasil belajar berupa nilai pretest dan nilai posttes.

\section{Kelayakan Pengembangan Modul IPA}

Terpadu Berbasis Discovery Learning

Pada Materi Sistem Pernapasan

Manusia Kelas VIII SMP YPK 2 Manokwari.

Pengujian kelayakan modul IPA terpadu berbasis discovery learning pada materi sistem pernapasan manusia dilakukan oleh dosen Program Studi Magister Pendidikan IPA FKIP Universitas Cenderawasih sebagai validator materi.Dengan menggunakan angket yang diisi oleh tiga orang validator.

Berdasarkan hasil penilaian ketiga orang validator materi tererhadap modul IPA terpadu berbasis discovery learningdiperoleh hasil penilaian presentase skor rata-rata $94,70 \%$ dengan kategori sangat layak. Sehingga modul ini layak digunakan sebagai media pembelajaran.

Hasil Uji coba modul IPA terpadu berbasis discovery learning pada uji coba 
skala terbatas diperoleh hasil presentase skor rata-rata $88,78 \%$ dengan kriteria sangat baik dan hasil uji coba skala luas yang dilakukan untuk mengetahui tanggapan guru terhadap modul, peningkatan motivasi peserta didik, dan peningkatan hasil belajar pada materi sistem pernapasan manusia.

Berdasarkan hasil tanggapan guru terhadap modul modul IPA terpadu berbasis discovery learning pada materi sistem pernapasan manusia yang dikembangkan diperoleh hasil presentase rata-rata sebesar $93 \%$ dengan kriteria sangat baik. Hal ini sejalan penelitian yang dilakukan oleh Rosalina Esti Lestari dan Virman (2018) bahwa modul fisika layak digunakan melalui discovery learning dengan menerima saran dan penilaian dari angkatan kepada teman sejawat validator media dan validator materi.

\section{Motivasi Belajar Peserta didik} Menggunakan Modul IPA Terpadu Berbasis Discovery Learning.

Berdasarkan hasil analisis motivasi belajar peserta didik menggunakan intrumen berupa angket, setiap perbutir pertanyaan dapat diketahui hasil presentase tanggapan peserta didik terhadap modul IPA terpadu materi sistem pernapasan manusia yang dikembangkan, memberikan tanggapan positif sebesar $100 \%$ dengan kriteria sangat tinggi. Berdasarkan hasil tersebut, maka modul IPA terpadu berbasis discovery learning yang dikembangkan dapat menarik motivasi belajar peserta didik untuk belajar.

Penilaian observasi motivasi belajar peserta didik selama pembelajaran berlangsung. Pengamatan ini bertujuan untuk mengetahui peran modul IPA terpadu terhadap motivasi belajar peserta didik saat melakukan aktivitas pembelajaran. Motivasi belajar peserta didik yang dinilai ada 12 jenis, yaitu memperhatikan, bertanya, mengerjakan tugas, memanfaatkan waktu, membaca buku, berdiskusi, tekun, tidak mudah putus asa, tidak malu, berusaha, percaya diri, berani sehingga diperoleh hasil presentase ratarata motivasi belajar peserta didik secara keseluruhan sebesar $81,83 \%$ didapat dari RPP-1 79,86\%，RPP-2 80,77\%，RPP-3 $84,85 \%$.

Persentase motivasi belajar peserta didik terhadap modul IPA disajikan pada gambar 2 berikut ini :

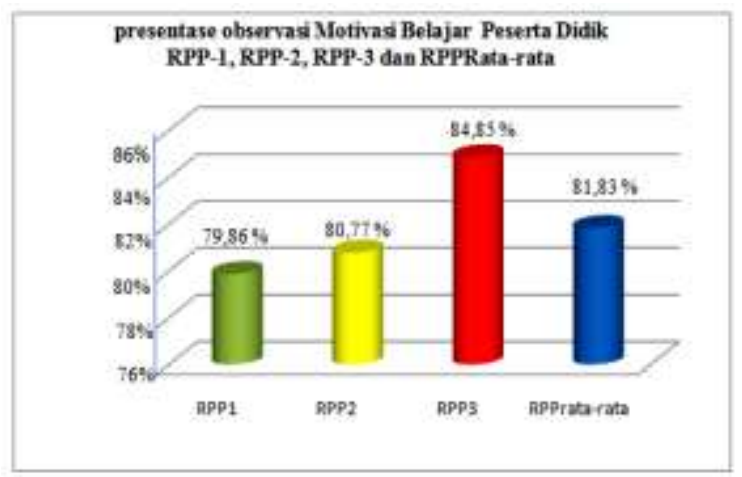

Gambar 3 Diagram Batang Persentase Observasi Motivasi Belajar Peserta Didik RPP-1,RPP-2,RPP-3 dan RPP Rata-rata.

Berdasarkan gambar 2 menunjukkan bahwa motivasi belajar peserta didik pada 
RPP1 sampai RPP3 mengalami peningkatan sebesar $4,99 \%$.

\section{Hasil Belajar Peserta Didik Dengan} Menggunakan Modul IPA Terpadu Berbasis Discovery Learning.

Hasil belajar RPP 1 sampai RPP 3 diperoleh nilai pretest rata-rata 39,06 nilai posttest rata-rata 70 sehingga ada peningkatan sebesar 30,24. Hasil uji n-Gain diperoleh $n$-Gain rata-rata 0,51 dengan penguasaan konsep peserta didik termasuk dalam kategori sedang. Nilai rata-rata posttest yang diperoleh peserta didik pada RPP-1 sebesar 69,39 mengalami penurunan sebesar 0,3 pada RPP-2 dengan nilai ratarata posttest yang diperoleh peserta didik 69,09. Hal ini disebabkan karena materi pembelajaran pada RPP-1 tentang pengenalan bagian organ sistem pernapasan manusia dan frekuensi pernapasan manusia melalui praktikum masih bersifat sederhana selanjutnya setelah masuk ke RPP-2 tentang mekanisme sistem pernapasan dada dan perut dan mengukur volume pernapasan melalui praktikum. Nilai rata-rata posttest RPP-2 ke RPP-3 mengalami peningkatan sebesar 2,43 pada RPP-3 dengan rata-rata nilai posttest sebesar 71,52. Hal ini karena peserta didik sudah mulai terbiasa melaksanakan aktivitas pembelajaran di RPP-3 yang hanya mengidentifikasi gangguan penyakit sistem pernapasan manusia dan cara penanggulangan, serta sudah terbiasa mengerjakan soal yang diberikan pada RPP-1 dan RPP-2 sehingga ketika masuk pada aktivitas kegiatan pembelajaran pada RPP-3 sudah mengalami peningkatan.

Berdasarkan hasil belajar pada RPP-1 diperoleh hasil uji $n$-Gain diperoleh nilai $n$ Gain sebesar 0,53 maka penguasaan konsep peserta didik termasuk dalam kategori sedang, mengalami penurunan sebesar 0,02 pada RPP-2 dengan rata-rata $\mathrm{n}$-Gain sebesar 0,51 . Kemudian nilai $\mathrm{n}$-Gain mengalami penurunan kembali sebesar 0,03 pada RPP3 dengan rata-rata $\mathrm{n}$-Gain sebesar 0,48 termasuk kategori sedang. Hal ini disebabkan kemampuan peserta didik didalam memahami materi pembelajaran yang diberikan, untuk setiap peserta didik berbeda-beda, ada yang cepat menerima,dan ada juga yang lambat didalam menerima materi pembelajaran yang disampaikan oleh guru serta waktu yang sangat singkat pada saat dilakukan posttest.

Hasil uji n-Gain yang diperoleh pada RPP-1 sampai RPP-3 dirata-ratakan sehingga diperoleh rata-rata $n$-Gain 0,51 dengan kategori sedang. Hasil penelitian dari Tiurlina Siregar dan Desry Natalia (2019) bahwa peningkatan hasil belajar peserta didik dapat dipengaruhi modul pembelajaran yang digunakan. Hasil nilai uji $n$-Gain rata-rata ini tergolong sedang sehingga modul IPA terpadu berbasis discovery learning disimpulkan dapat meningkatkan hasil belajar peserta didik. 


\section{SIMPULAN DAN SARAN}

SIMPULAN

Modul IPA terpadu berbasis discovery learning pada materi sistem pernapasan manusia layak untuk digunakan peserta didik kelas VIII SMP YPK 2 Manokwari karena diperoleh kelayakan modul dari validator sebesar 94,70\% dengan kategori sangat layak, guru IPA sebesar 93\% dengan kategori sangat baik, dan peningkatan hasil belajar peserta didik yaitu $n$-Gain rata-rata sebesar 0,51 dengan kategori sedang.

\section{SARAN}

Perlu dilakukan pengembangan modul IPA terpadu berbasis discovery learning pada materi yang lain.

\section{UCAPAN TERIMAKASIH}

Kepada Kepala Sekolah SMP YPK 2 Manokwari, kami ucapkan terimakasih yang telah memfasilitasi tempat dan membantu biaya untuk terlaksananya penelitian ini.

\section{DAFTAR PUSTAKA}

Ananda, Rusydi dan Abdillah, 2018, Pembelajaran terpadu: karakteristik, landasan, fungsi, Prinsip dan mode, Lembaga Peduli Pengembangan Pendidikan Indonesia (LPPPI), Medan. ISBN 978-602-51316-1-5;

Delisma Wisnu Adi, 2016, Pengembangan modul Fisika berbasis discovery learning dengan pendekatan problem based learning untuk meningkatkan kemampuan berpikir kritis dan kreatif siswa kelas XI SMA/MA di Surakarta, Tesis S2, Program Magister Pendidikan Sains
Universitas Sebelas Maret Surakarta;

https:// puspendik. kemdikbud. go.id / hasilun / diakses tanggal 29 November 2018.

https:// puspendik. kemdikbud. go.id /seminar /upload/ Hasil \% 20 Seminar \% 20 Puspendik \% 20 2016 / Nizam-asi 1\% 20 Penilaian seminar \% 20 puspendik \% 20 2016. pdf. Belajar Dari Hasil UN, PISA, TIMSS, INAP. Pusat Penilaian Pendidikan. Badan Penelitian dan Pengembangan/ diunduh tanggal 10 Januari 2019

Rosalina Esti Lestari dan Virman; Pengembangan Modul Pembelajaran Fisika Berbasis Discovery Learning Pada Materi Vektor Peserta Didik Kelas X SMA KPG Khas "Papua" Merauke, Jurnal Ilmu Pendidikan Indonesia Vol 6 (3), 83-92;

Sugiyono, 2016, Metode Penelitian kuantitatif, kualitatif, dan $R \& D$. Bandung: Alfabeta;

Tiurlina Siregar dan Desry Natalia; Modul Pembelajaran Inkuiri Terbimbing Pada Materi Larutan Elektrolit Dan Non Elektrolit, Jurnal Ilmu Pendidikan Indonesia Vol 7 (1) 8 16. 